\title{
Birth of Violent Criminal Behavior and the Social Liability: A Qualitative Investigation in Bangladesh
}

\author{
Mahmuda Akter* \\ Assistant Professor, Department of Criminology and Police Science, \\ Mawlana Bhashani Science and Technology University, Tangail, Bangladesh \\ Moonmoon Binta Aziz \\ Assistant Professor, Department of Criminology and Police Science, \\ Mawlana Bhashani Science and Technology University, Tangail, Bangladesh
}

\begin{abstract}
It has become notorious concern that the society is nurturing all criminals but it is factual that societies have the liability of her every affiliate. The main objective of the study is to identify how entire society has become responsible for creating the scope of violent crimes in Bangladesh. This paper also identifies the changing pattern of criminal behavior and examines how social institutions become liable in creating violent incident as well as uncovered the challenges of social reintegration of violent offenders in Bangladesh. This study is qualitative in nature that follows secondary data analysis method where thematic analysis is used. This study finds that violent crime changes in more violent pattern in Bangladesh. Besides, the scope of violent criminal behavior lies not only in violence in family, educational institutions, community of violent criminals but also disputing impact of justice system. Besides, this study also indicates that violent offenders are confronted by a vast range of socio-economic challenges that causes obstacles to their social integration in society.
\end{abstract}

Keywords: Violent Criminal Behavior, Social Liability, Social Reintegration.

DOI: $10.7176 / \mathrm{JLPG} / 95-10$

Publication date:March $31^{\text {st }} 2020$

\section{Introduction}

Violent crimes are the most crime in the present time all over world. Violence is a behavior by persons, against persons or property that purposely threatens, attempts, or actually imposes physical damage. A violent crime is an offence in which the offender practices or impends violent power upon victim. The numbers of violent criminal activities are increasing day by day in Bangladesh. Lack of equal justice, prolonged investigation and criminal procedure, failure of arresting real offender and identifying the real facts of offence, social discrimination, media influence, excessive drug abusing, political conflicts, ideological conflict, social conflicts and family conflicts are working as the main responsible factors for the high rate of violent criminal behavior in Bangladesh. Violent crimes like murder, rape, women and child repression and robbery have been increased rapidly in recent years which affect our social harmony, development, fear of crime, feeling of insecurity and peaceful situation of the country. The trend of violent crime has been changing in Bangladesh from the very beginning of $21^{\text {st }}$ century through bomb attack on Pahela Baishakh festival (Bengali New Year Celebration), political violence, internal and external ideological conflict, extra-judicial killing, murder of bloggers and atheist etc. Terrorist groups like Harkatul Jihad, Hijbut Tahri, JMB (Jamaetul Mujahedin Bangladesh), Ansarullah Bangla Team and many other extremist terrorist groups have been killing so many innocent people in recent years. Regular incidents results human rights violations as normal phenomenon.

Social liability is a duty every individual has to perform within an ethical framework and suggests that an entity, be it an organization or individual, has an obligation to act for the benefit of society at large. It is the crying need of today to ensure the social liability for violent offenders because violent offenders are confronted by a range of social, economic and personal challenges that tend to become obstacles to their social integration. Some of those challenges are a result of the offender's social environment, family, peer group, substance abuse or low education and skill levels. Criminals may have a past of social isolation and marginalization, physical or emotional abuse, poor employment or unemployment, and participation in an illegal lifestyle that originated at an early age (Brown and Dandurand, 2007). Many offenders suffer from serious skill deficits that make it difficult for them to compete and succeed in the community such as poor interpersonal skills, low levels of formal education, illiteracy or innumeracy, poor cognitive or emotional functioning, a lack of planning and financial management skills etc (Losel and Bender, 2003).

The questions come in attention of all that is the society missing some responsibility to prevent people from the involvement of violent criminal activity? Now, it has become essential to know the present trends of violent criminal behavior to prevent the birth of violent criminal from the Bangladesh society. All classes of people including street children, university teachers and students, foreigners, Muslims, non- Muslims, political leaders, reporters, bloggers, atheist, and women are becoming victim of violent criminal incidents in different places in 
different modes (Harper and Chitty, 2005). There remains very small number of research on these issues nationally and internationally that focus on the root causes of the birth of violent criminals which has become extreme need in nowadays.

This paper is an effort to represent how the entire society has become responsible for creating violent criminals in Bangladesh. This paper also identifies the changing pattern and risk factors of violent crime as well as find out the challenges of social reintegration of violent offenders in society.

\section{Objectives}

The primary objective of this study is to know how society has become liable in promoting the birth of violent criminals in Bangladesh. To fulfill the main objective, some additional objectives are as follows:

i. To identify the changing pattern of violent Murder in recent years in Bangladesh.

ii. To examine how social institutions become liable in creating violent incident in Bangladesh.

iii. To find out the challenges of social reintegration of violent offenders in Bangladesh.

\section{Methodology of the Study}

This study is qualitative in nature and the entire study was conducted as qualitative manner through using secondary source and also the information were collection within the same method. Here, content analysis is used where data had collected from Bangladesh Police Statistics from June, 2016 to December, 2016 through a selfcompletion checklist including some recent cases on violent crime incidents in Bangladesh. Besides, information were also collected from different relevant sources like-books, journals, articles, periodicals and NGOs; like Ain O Salish Kenrda (ASK) And ODHIKAR and related research papers on violent crimes in Bangladesh. The content analyses were processed through examining particular checklist, coding and categorization procedure. Most importantly, thematic analysis used for the analysis of all collected information from different sources.

\section{Findings-Thematic Analysis}

4.1 Changing Patterns of Violent Murder Incidents in Bangladesh (2011-2016)

According to Bangladesh police statistics (2011), about 3966 murder incidents occurred in 2011 which shows that about 11 people were murdered in a day averagely on that year. That year was full of inhuman murder incidents by the eve-teasers because not only the students but also their parents, brothers and relatives had to give their lives for violent crime associated with eve-teasing. About 740 women were murdered by the eve-teasers, about 400 women committed suicide due to sexual harassment and eve-teasing and 294 were murdered due to dowry (bdnews24, 7 January, 2012). Moreover, according to Bangladesh police statistics (2012 and 2013), about 4114 murder incidents occurred in 2012 and 4393 murder incidents occurred in 2013 where 11 people were murdered in a day averagely on that year. In that year, murder of Bloggers, Free-thinkers, Atheist was started in a new dimension. Murder of Rajib Haider (Blogger) was the first visible sign of religious extremism and religious terrorist activities in the country. Besides, there occurred several political murders in this year. About 507 people were died due to political conflict especially due to election violence.

According to Ain O Salis Kendra (2014), news reporter Sagor and Runi were murdered in $11^{\text {th }}$ February in their own flat which was regarded as one of the most sensitive case throughout the country. Child murder increased in that year and the number was 414 . About 208 women were killed by their husband and another 45 women were killed by the relatives of their husband. Political violence due to election was the main cause of the high rate of murder of that year. Using lethal chemical and weapon in strike like using petrol bomb was a pathetic seen of that year as many innocent people died after burning by the petrol bombs. Vindicating political relation starts against from this year as main opposition party didn't participate in the national election. That condition is continuing till today and many internal and external political conflicts are taking lives of many people everywhere in our country.

Furthermore, according to Bangladesh police statistics (2014,) about 4514 murder incidents occurred in 2014 where over 12 people were murdered in a day averagely on that year. In recent years, the highest number of murder incidents occurred in 2014. Political leaders, lawyers, teachers and general people were the main victim of murder in that year. Most importantly, on 15 November 2014, a teacher of Rajshahi University sociology department named Shafiul Islam, a follower of the Baul community, was struck with sharp weapons by several youths on his way to home. A fundamentalist Islamic militant group named 'Ansar al Islam Bangladesh-2' claimed responsibility for the attack (Daily Prothom-Alo, October 17, 2014). Religious extremist groups were very much active on this year but they started to kill indiscriminately in the next year.

According to Bangladesh police statistics (2015), about 4035 murder incidents occurred which reminds us about the barbaric murder of several murders of Bloggers and the cruel murder of children like Samiul and Rakib. Murder of atheist, bloggers, and free-thinkers were the main issues. Besides, from 2015 the terrorist activities have emerged in a new dimension because about 30 people had been killed in 2015 by terrorist activities. (Daily Prathom Alo, $11^{\text {th }}$ June, 2016). Blogger Anonto Bijoy Das, Avijit Roy, Oyaishikur Rahman, Niladri Chattopadhyay Niloy, Faisal Arefin Dipan and Nazimuddin Samad were murdered by the religious extremist groups. 
Bangladesh police statistics (2016) also shows, about 2144 murder incidents was occurred in 2016 from January to July. That means, over 10 people have been killed in this first 7 month in a day averagely. Though the average number of murder has not increased from the recent couple of years, the nature of murder like terrorist activities and murder has become a great problematic issue. The terrorist attack on Holy Artison Bakary (Restaurant) targeting the foreigners especially the non-Muslims is the great concerning issue of this year. Failure to take necessary steps as soon as possible to combat terrorist activities results to face great problems of religious terrorist activities. Different types of murder incidents and the diverse causes of those incidents are rising in an alarming rate. Violent criminals target the people like, Hindu priest, Saint, Buddhist nuns, Christian priest, Shea, fans of Lalon, followers of Pir, workers of Gay rights, Bloggers, Writers, Publishers, University teachers and also the police personnel and their family members.

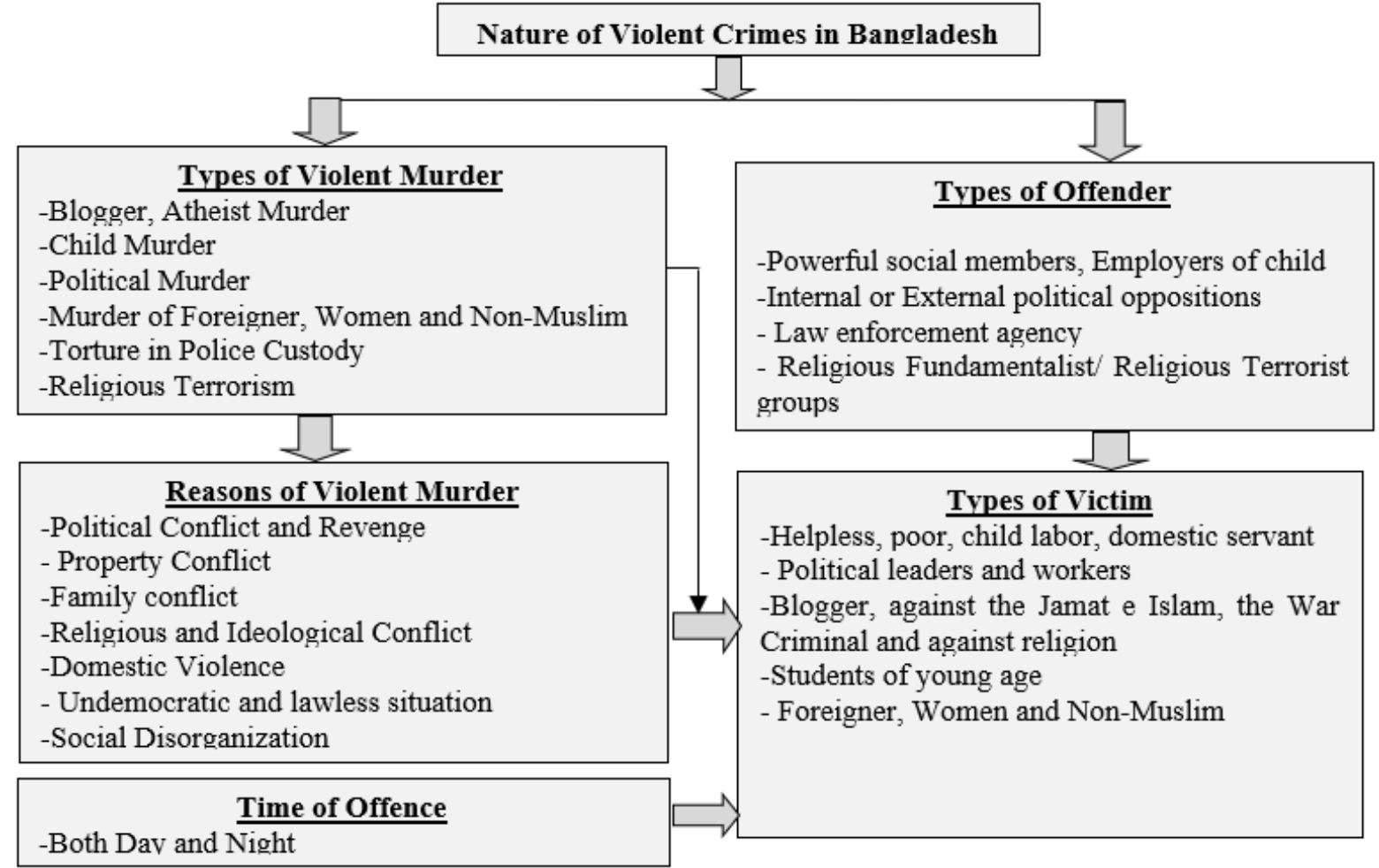

Figure No 1: Nature of Violent Crimes in Bangladesh

\subsection{Liability of Social Institutions in the Birth of Violent Criminals}

4.2.1 Violence in the Home and Family

Involvements of violent crime are often linked to stressful living circumstances in the family. Parental use of physical violence to build discipline children in early age is a traditional and long-accepted pattern of parenting (Losel and Bender, 2003). For this reason, a high rate of corporal punishment in families is continuing. From this study, violent offenders claimed that they were slapped, punched, kicked, and beaten by their parents, sometimes with an object. In majority of family time, they were left alone, given inadequate food, clothing, or medicines, or be exposed to drugs or weapons in the home as well as sexually and psychologically abused in Bangladesh. That negligence in adulthood consequences in higher rates of mental illness, increased rates of drug or alcohol abuse, difficulties forming relationships, and compromised brain development and gradually involved them in violent criminal activity.

\subsubsection{Violence in Educational Institutions}

When teachers are trained in children's rights and positive classroom management strategies, the rates of violence in the educational institutions go down (Brown and Dandurand, 2007). In the educational institutions of Bangladesh, individual of all ages are subjected to harsh and humiliating verbal abuse, corporal punishment, bullying, and sexual victimization and harassment. They are exposed to this violence in classrooms, in playgrounds, and on their journeys to and from educational institute. They suffer violence at the hands both of their teachers and their peers. Not only is such teacher behavior damaging to the child's self-esteem, but also it creates a very poor classroom climate, which discourages learning and promotes peer bullying. Specially, the number of violent crime is also increasing in the university level with the serious level of corruption and bad political influences.

4.2.3 Violence in the Community

Even though there has been an increase in national wealth worldwide, the distribution of this wealth is far from 
equitable in Bangladesh. Our society in many ways still reproduces the "two-tier" structure and relationships of apartheid, although in a slightly de-radicalized form, the degree of inequality creates a high degree of relational distance between people that reinforces perceptions partly derived from the apartheid period. The cost-benefit analysis of based on income inequality sometimes enforces the people to be involved in not only in violent criminal activity but also become recidivist for violent crime (Fajnzylber and Loayza, 1999). Majority of violent criminals continue to be exposed to violence in their communities. The area in which they live affects the cause and type of that violence, whether it is gun and gang violence. The political, social, and economic conditions increases vulnerability to trafficking and street involvement provide fertile ground for the formation of, and recruitment to, youth gangs, drug abuse, civil and political unrest, murder, terrorist activity etc.

4.2.4 The Disputable Impact of the Criminal Justice System

Due process-based systems rely substantially on the consistent application of basic investigation procedures and techniques, and on the skills of police and prosecutors, in order to successfully investigate and prosecute cases especially for violent crime. A large number of people are actually apprehended and prosecuted every year, and many thousands are imprisoned. While imprisonment serves a temporary incapacitating function, most of those who are imprisoned spend relatively short periods in prison. Whether they are merely arrested or are imprisoned, the interactions offenders have with the criminal justice system often have little impact on discouraging reoffending and often seem to increase the risk of such behavior. Torture is routinely used by the police in Bangladesh. During 2004- 2015(April) in total 394 accused (alive 231, dead 163) were allegedly tortured by police. For the period of the first six months of 2015, three persons were allegedly tortured to death by the police where two persons were reported beaten to death; one was beaten to death by the police, 30 persons were shot in the leg by the law enforcement agencies after arrest (ODHIKAR, 2015). Besides, 10 persons were allegedly tortured to death by the police in 2014 and in 2013 while 5 persons were dead in 2012, 14 persons were dead in 2011 whereas 20 persons were dead in 2010 (ODHIKAR, 2014). Moreover, police brutality is not as endemic as it was under apartheid, but there is still a substantial problem of police violence, spurred on in part by more generalized anger about violent crime. Police violence is part of, and reinforces, the normalization of violence, and undermines respect for the law. Correctional officials also reflect societal attitudes that are hostile towards offenders in allowing an environment of violence to flourish within prisons, as they do not regard prison inmates as being worthy of protection against violence.

\subsection{Social Exclusion and reintegration challenges of violent criminals}

4.3.1 Dying the re-adjusting scope for violent criminals

In Bangladesh, violent criminals are not getting proper reintegration scope in the society. But all individuals are expected to be free and functional to their society base on the all-inclusive mutuality and this can be achieve beyond just a mare facilitating basic survival processes that include social relationships, reproduction, achieving basic humans derives (Baumeister, 1991), which shows greater capability of an individual member to deal and manage any problem faced also likely to be associated with little or no antisocial or criminal behaviors (Sampson and Laub, 1993).

Thus, it is imperative and essential for violent criminals existence to allow and enable individual to adjust and acclimatize with their cognitive and behavior so as to identify and avoid the danger of being socially excluded from their societies and also to come up with ways of adapting and re-affiliating position (Baillargeon, Hoge and Penn, 2010). The primary criminogenic needs that must be talked by institutional and community based management programs are connected to education, employment, accommodation, drugs and alcohol, mental health, social networks, cognitive skills, and attitudes (Baumeister, 1991).

4.3.2 Social exclusion leads to violent recidivism

Violent offenders lose all of their rights and many times their dignity. Not only do they lose rights but they lose the ability to take care of themselves. They are no longer required to put in any effort to meet their own basic needs; therefore they lose the ability to do so (Wheeler and Patterson, 2008). They are dehumanized and forced into more crime and gang related activity than on the streets just so they can survive.

Violent released or reoffended prisoner constitute a relatively small percentage of the offender population (MacDonald and Leary, 2005). However, it tends to be more problematic to engage them in treatment than other offenders and their social reintegration presents a difficult challenge. Repeat violent offenders, in particular, tend to have poor coping or a problem-solving skill, which undermines their social interactions and social integration (Burke, 2001).

Moreover, the combination of the above mentioned factors can make an individual violent offender to develop a sense of worthlessness is being socially excluded which may have a damming consequences on both physical, psychological as well as social effects on an individual (Keicolt, Messick and Speicher, 1984). By implication these factors could contribute immensely towards going back to the previous criminal activities that lead to the initial arrest, conviction and sentencing to prison offender would have a tendency of becoming violent criminal recidivist (Casey and Jarman, 2011). 


\subsubsection{Demand of effective discharge plan for ex-offenders}

Aside from individual barriers Wheeler and Patterson identify barriers within the system such as overburdened parole system and lack of alternative sentencing options and sanctions (Baumeister, 1991). Ex-offenders have so much working against them that it is imperative for social workers and the criminal justice system to implement effective discharge plans that prepare serious violent offenders for success rather than recidivism (Petersilia, 2004). Lattimore (2007) adds barriers offenders in reentering the community that are inhibiting successful reentry within systems, such as criminal justice, mental health, education, and financial must be addressed. In other words, preventative actions are not effective for all violent criminals. Obstacles to effective community reentry have become a long list that investigators and policy makers are beginning to identify. However unless there is acknowledgement of how extensive and difficult these barriers are it seems there are unrealistic expectations of finding the magic bullet that will cure recidivism (Borzycki, 2005).

4.3.4 Establishing the need of Social reintegration

The concept of 'reintegration' involves both addressing the needs of the released prisoners and managing the risk the offenders may pose to the community. In the field of criminal justice, 'social integration' refers to programmes and measures which aim to facilitate an offender's social and psychological adaptation into their family, school, workplace, community and society (Suldo, Riley and Shaffer, 2006).

In general, there are two main categories of social reintegration programme (Brown and Dandurand, 2007): (a) programmes and interventions offered in the institutional setting itself, in advance of the offenders' release, to help them resolve issues, address risk factors associated with their criminal behaviour and acquire the necessary skills to lead law-abiding and self-supporting lives, as well as to prepare them for their release and re-entry into society; and (b) community-based programmes, sometimes part of a conditional release scheme, to facilitate the social reintegration of offenders after their release from custody (Baillargeon, Hoge and Penn, 2010).

In recent years, post-release interventions, including community-based interventions, have been variously referred to as 'aftercare', 'transitional services' or 'social reintegration' or 'resettlement' programmes (Griffiths, Dandurand and Murdoch, 2007). Re-entry typically occurs at the end of a custodial sentence or other form of detention, but it can also occur earlier as part of a conditional release programme, sometimes under formal supervision and sometimes without any supervision or assistance at all (Eisenberger, Lieberman and Williams, 2003). The re-entry process is a transition full of emotional significance and practical difficulties for the offenders. It may supplementary position challenges for the offenders' families and the broader community. Successful programmes are usually those which have raised public awareness of the issue and worked with local communities to make the reintegration of offenders possible (Losel and Bender, 2003).

The treatment of dangerous high-risk offenders is ultimately aimed at preventing repetition of their inappropriate, dangerous or criminal behavior. This is frequently referred to as the 'relapses prevention' approach. Relapse can be understood in terms of the lack of lasting effect of the treatment followed (Hollin, 1989). In fact, recidivism may be considered the result of a failure to maintain treatment effects. This raises the question of how the effect of treatment can be reinforced after a prisoner's release and during the aftercare period. Through cognitive and behavioural means, a relapse prevention approach teaches offenders new ways of coping that may allow released or reoffended prisoner to break the cycle before they relapse completely (Suldo, Riley and Shaffer, 2006).

\section{Conclusion}

Violent criminal activities restrain the development and peaceful situation of Bangladesh. In the recent past five years, the rate has increased in a high level. But at present, the nature, extents, cause of violent crime incidents are changing. Law enforcement alone cannot prevent violence from society. The roots of violent crime must be addressed in all systems of government. There are a multitude of failures throughout the criminal justice and other systems that continue to drive violent crime. The underlying causes of criminal behavior range as widely as the psychology, physiology, and sociology of individual members of society. Poverty, lack of education, inaccessibility of housing, unemployment, lack of services for the mentally ill, and many other 'broken' pieces and systems contribute to violent crime. Some of these causes, at least to a degree, fall within the scope of law enforcement; yet most require a more holistic governmental approach. These systemic causes must be addressed differently than the crimes that often are driven by a small number of high-risk offenders. So, to prevent the scope of birth of violent criminal activity in society, it has become essential to ensure the exact role of every member of the society with their own liability.

\section{References}

Ain O Salish Kendra (ASK), Report (2016-2014). Retrieved at July, 2016 from http://www.askbd.org

Baillargeon, J., Hoge and Penn, J., V. (2010). Addressing the challenge of community reentry among released inmates with serious mental illness. Journal of American Jails Community Psychology, vol 46(1)

Baumeister, R. F. (1991). Meanings of life. New York, NY: Guilford Press. 
Bangladesh Police Statistics, (2011-2015) Retrieved at July, 2016 from http://www.police.gov.bd/CrimeStatistics-comparative.

Burke, P. B. (2001). Collaboration for Successful Prisoner Re-entry: The Role of Parole and the Courts. Corrections Management Quarterly Paper, 5(3).

Bdnews24.com Retrieved at July, 2016.

Brown, R. E. and Dandurand Y. (2007). Successful Strategies that Contribute to Safer Communities, Selected Papers on Successful Crime Reduction and Prevention Strategies in the Urban Context, Naif Arab University for Security Sciences, Riyadh.

Borzycki, M. (2005). Interventions for Prisoners Returning to the Community. A Report Prepared by the Australian Institute of Criminology for the Community Safety and Justice Branch of the Australian Government Attorney General's Department. Canberra: Australian Institute of Criminology, Retrieved at August 13, 2016 from http://www.aic.gov.au/publications/reports/2005- 03-prisoners.html

Casey, J., and B. Jarman. (2011). The Social Reintegration of Ex-Prisoners in Council of Europe Member States. Quaker Council for European Affairs, Brussels. Retrieved at August 13, 2016 from www.cepprobation.org/uploaded_files/rprt-reintegration-full-en-may-2011.pdf.

Eisenberger, N. I., Lieberman, M. D., and Williams, K. D. (2003). Does Rejection Hurt? A Study of Social Exclusion, Journal of Social Science Science, Vol 302

Fajnzylber, P., D. Lederman and Loayza N. (1999). Inequality and violent crime, mimeographed, World Bank, Washington, DC.

Griffiths, C. T., Dandurand Y. and Murdoch, D. (2007). The Social Reintegration of Offenders and Crime Prevention. Public Safety Canada, National Crime Prevention Centre, Ottawa. Retrieved at August 13, 2016 from www.publicsafety.gc.ca/res/cp/res/_fl/soc-reint-eng.pdf.

Harper and Chitty, C. (2005). The Impact of Corrections on Re-offending: A Review of 'What Works, London, Home Office, Research, Development and Statistics Directorate.

Hollin, CR .(1989). Psychology and Crime: An introduction to criminological psychology. London, Routledge and Keagan Paul Press.

Keicolt, Glaser. Messick, G. and Speicher, C. (1984). Urinary Cortisol levels, Cellular immune Competency, and Loneliness in Psychiatric Inpatients. Psychosomatic Medicine Journal, Vol 46.

Lattimore, P., K. (2007). The challenges of reentry. Corrections Today Special paper, Edition 62(2).

Losel, F. and Bender, D. (2003). Protective factors and resilience in Early Prevention of Adult Antisocial Behaviour, Cambridge, Cambridge University Press.

MacDonald, G., and Leary, M. R. (2005). Why does Social Exclusion Hurt? The Relationship between Social And physical Pain. Psychological Bulletin, Edition 131.

ODHIKAR. (2015). Torture and ill-treatment in Bangladesh. Retrieved at May 4, 2015 from http:/odhikar.org/human-rights-monitoring-report-january-june-2015/

ODHIKAR. (2014). Fact Finding of Torture. Retrieved at May 5, 2015 from http://1 dgy051vgyxh41o8cj16kk7s19f2.wpengine.netdnacdn.com/wpcontentuploads/2013/06/Fact-Findingdisappearance-Mahobbat-Kustia-2013-Eng.pdf

Sampson, R. J. and Laub, J. H. (1993). Crime in the Making: Pathway and Turning Points Through Life. Cambridge, MA: Harvard University Press.

Suldo, S.M., Riley, K. and Shaffer, E.S. (2006). Academic Correlates of Children and Adolescents' Life Satisfaction. School of Psychology International, Vol 27, and Retrieved at August 20, 2016 from http://dx.doi.org/10.1177/0143034306073411

The Daily Prothom Alo, October 17, 2014 Retrieved from http://epaper.prothom-alo.com/view/dhaka/2014-1117/20)

The Daily Prothom Alo, June 11, 2016 Retrieved from http://epaper.prothom-alo.com/view/dhaka/2016-06-17/20) 